OPEN ACCESS

Edited by:

Takao K. Hensch,

Harvard University, USA

Reviewed by:

Janice R. Naegele,

Wesleyan University, USA

Sunil P. Gandhi,

University of California, Irvine, USA

*Correspondence:

Muhammad O. Chohan chohanm@nyspi.columbia.edu

Holly Moore

mooreho@nyspi.columbia.edu

Received: 15 April 2016 Accepted: 02 August 2016 Published: 17 August 2016

Citation:

Chohan MO and Moore H (2016) Interneuron Progenitor Transplantation to Treat CNS Dysfunction.

Front. Neural Circuits 10:64. doi: 10.3389/fncir.2016.00064

\section{Interneuron Progenitor Transplantation to Treat CNS Dysfunction}

\author{
Muhammad O. Chohan ${ }^{1,2 *}$ and Holly Moore ${ }^{1,2 *}$ \\ ${ }^{1}$ Department of Integrative Neuroscience, New York State Psychiatric Institute, New York, NY, USA, ${ }^{2}$ Department of \\ Psychiatry, Columbia University, New York, NY, USA
}

Due to the inadequacy of endogenous repair mechanisms diseases of the nervous system remain a major challenge to scientists and clinicians. Stem cell based therapy is an exciting and viable strategy that has been shown to ameliorate or even reverse symptoms of CNS dysfunction in preclinical animal models. Of particular importance has been the use of GABAergic interneuron progenitors as a therapeutic strategy. Born in the neurogenic niches of the ventral telencephalon, interneuron progenitors retain their unique capacity to disperse, integrate and induce plasticity in adult host circuitries following transplantation. Here we discuss the potential of interneuron based transplantation strategies as it relates to CNS disease therapeutics. We also discuss mechanisms underlying their therapeutic efficacy and some of the challenges that face the field.

Keywords: stem cell therapy, GABA, medial ganglionic eminence, excitation-inhibition, neuropsychiatric disorders

\section{INTRODUCTION}

Since the turn of 20th century neural transplantation has been studied as a potential therapeutic strategy for neural reconstruction and repair (Cajal, 1928). Initial attempts with engraftment of neural tissue in lower vertebrates remained largely unsuccessful with most studies concluding that the adult brain was inhospitable for graft survival (Willis, 1935). However, several early studies showed promise with engraftment of developing tissue (Dunn, 1917; Tidd, 1932; Clark, 1940). Notably, one study (Clark, 1940) demonstrated viability of embryonic neocortical grafts dissected from 15 to 20 days old embryos transplanted in the young mammalian brain. Strikingly, the engrafted cells differentiated and migrated such that the graft showed laminar features and cell morphologies characteristic of the developing cerebral cortex. Later, transplanted neonatal and embryonic cells were shown to develop normal synaptic afferent and efferent connections with host brain and spinal neurons (Björklund et al., 1976; Lund and Hauschka, 1976; Jakeman and Reier, 1991). Moreover, differentiation and integration of transplanted cells within the adult striatum and hippocampus was shown to be associated with improvements in motor coordination and spatial learning (Low et al., 1982; Gage et al., 1983, 1984; Björklund and Stenevi, 1984). Later studies revealed details of the anatomical and functional integration of the grafted tissue into host circuits: neurons within intraspinal grafts that were effective in improving motor function were shown to extend axons along white matter tracts rostrally and caudally (Nornes et al., 1983; Jakeman and Reier, 1991; Li and Raisman, 1993), and form synaptic relays (Cummings et al., 2005; Lu et al., 2012). Together, these studies revealed wide ranging potential for neural stem cell transplantation in CNS disease therapeutics. 


\section{FACTORS AFFECTING VIABILITY AND FUNCTIONALITY OF A NEURONAL TRANSPLANT}

In several studies the ideal age of embryonic donor tissue has been shown to depend on the developmental stage of the donor tissue, the time window including neuronal proliferation and migration being optimal (Banker and Cowan, 1977; Kromer et al., 1983). This is consistent with the finding that isolated hippocampal neurons that have recently completed DNA synthesis and are in the process of migration showed long term survival in cultures as opposed to post-mitotic cells dissociated from the ventricular zone or the cortical plate (Banker and Cowan, 1977). Other favorable attributes of young tissue may include their relative insusceptibility to transplant procedure related trauma, as well as their particularly low $0_{2}$ consumption rate which may buoy their viability in new environments during the initial days after implantation (Shyh-Chang et al., 2013).

A major objective of transplant studies has been to determine factors that allow the grafted cells to integrate functionally into host circuits, as such integration is thought to be important for sustainable therapeutic effects. In early studies it was noted that some types of transplanted embryonic cells displayed minimal dispersion, with functional effects often limited to graft site. For example, while cells within embryonic nigral tissue grafted into the striatum of 6-OHDA lesioned rats differentiate into dopamine neurons, the neurons do not disperse, but rather form a dopamine "island" near the site of transplantation within the striatum. Considering these observations, major factors contributing to a transplant's long term functionality would be the age of donor tissue, its ability to demonstrate widespread dispersion and integration within host, as well as the use of disease relevant cell types.

\section{INTERNEURON PROGENITORS AS A CANDIDATE FOR CELL BASED THERAPY}

While the early studies served as proof-of-principle for the concept of cell based therapy, mechanisms by which transplanted cells modify diseased brain circuitries have remained largely unknown. With refined knowledge of neurodevelopment (Merkle and Alvarez-Buylla, 2006; Muotri and Gage, 2006; Fuentealba et al., 2015) studies carried out over the past two decades have now begun to offer mechanistic insights and renewed evidence for the therapeutic efficacy of cell transplantation in CNS diseases. Of particular relevance has been the use of $\gamma$-amino butyric acid (GABA)-ergic inhibitory neuron precursors (Wonders and Anderson, 2006; Tricoire et al., 2011; Southwell et al., 2014) (Figure 1). Constituting only about $20 \%$ of the adult cortical neuronal population, inhibitory neurons are potent regulators of normal brain function, sculpting the excitation-inhibition balance and entraining activity of neuron ensembles in brain circuits (Klausberger et al., 2003; Klausberger and Somogyi, 2008; Lewis et al., 2012). Maturation of GABA circuits has been shown to set off and regulate critical period plasticity in brain sensory systems, offering a putative neurobiological handle with which to interrogate neurodevelopmental origins of neurological disorders (Hensch, 2005). As such imbalances in excitation-inhibition and dysfunction of inhibitory interneurons are hypothesized to underlie several neurological disorders like schizophrenia (SCZ; Harrison, 2015), autism spectrum disorders (Peñagarikano et al., 2011), Alzheimer's disease (AD; AndrewsZwilling et al., 2010), Parkinson's disease (PD; Salin et al., 2009), epilepsy (Möhler et al., 2004), and neuropathic pain (NP) (Moore et al., 2002).

\section{EPILEPSY}

Impaired inhibition has been described as a key pathognomonic feature in animal models of (Sloviter, 1987; Cossart et al., 2001) and human patients with (de Lanerolle et al., 1989; Mathern et al., 1995) epilepsy. For example, studies in temporal lobe epilepsy, the most common type in adults, have revealed deficits in hippocampal pyramidal neuron distal dendritic domaintargeting interneurons, including interneuron subpopulations expressing somatostatin (SST; Buckmaster and Jongen-Rêlo, 1999; Cossart et al., 2001; Kobayashi and Buckmaster, 2003), neuropeptide Y (NPY; Mathern et al., 1995; Sundstrom et al., 2001), and calbindin (CB; Wittner et al., 2002). In addition, a decrease in the density of hippocampal basket and chandelier parvalbumin (PV) immunoreactive cells has been reported (DeFelipe, 1999; Arellano et al., 2004; Ogiwara et al., 2007); however, perisomatic GABA innervation appears to be intact (Wittner et al., 2001, 2005). Despite compensatory sprouting of interneurons (Mathern et al., 1995; Arellano et al., 2004) imbalances in input-output relationship of pyramidal cells (Cossart et al., 2001) result in abnormal cortical network activity (Ogiwara et al., 2007). Introducing functional GABAergic neurons hence provides a means of replacing lost or dysfunctional inhibitory cells and tempering increased electrical activity seen in epilepsy.

Many of the early interneuron progenitor transplantation studies were carried out in animal models of epilepsy. AlvarezDolado et al. (2006) provided the first electrophysiological evidence of functional integration of MGE derived neuronal precursors grafted into the juvenile brain. In this study, grafted MGE cells within the hippocampus migrated up to $\sim 5 \mathrm{~mm}$ from injection site at 2 months after transplantation, acquired molecular markers of mature GABAergic interneurons [by expressing GABA, PV, SST, calretinin (CR), and NPY] and increased GABA mediated synaptic inhibition in regions containing transplants. In a series of follow-up studies, therapeutic efficacy of MGE progenitors was demonstrated by the reduction of severity and frequency of seizures in genetic (Baraban et al., 2009; Hammad et al., 2015) and acquired (Hunt et al., 2013; Henderson et al., 2014; Jaiswal et al., 2015) rodent models of epilepsy and hippocampal disinhibition (Calcagnotto et al., 2010; Waldau et al., 2010). Notably, while MGE cell transplantation in the hippocampus increased inhibitory postsynaptic current (IPSC) frequencies in host pyramidal (Baraban 


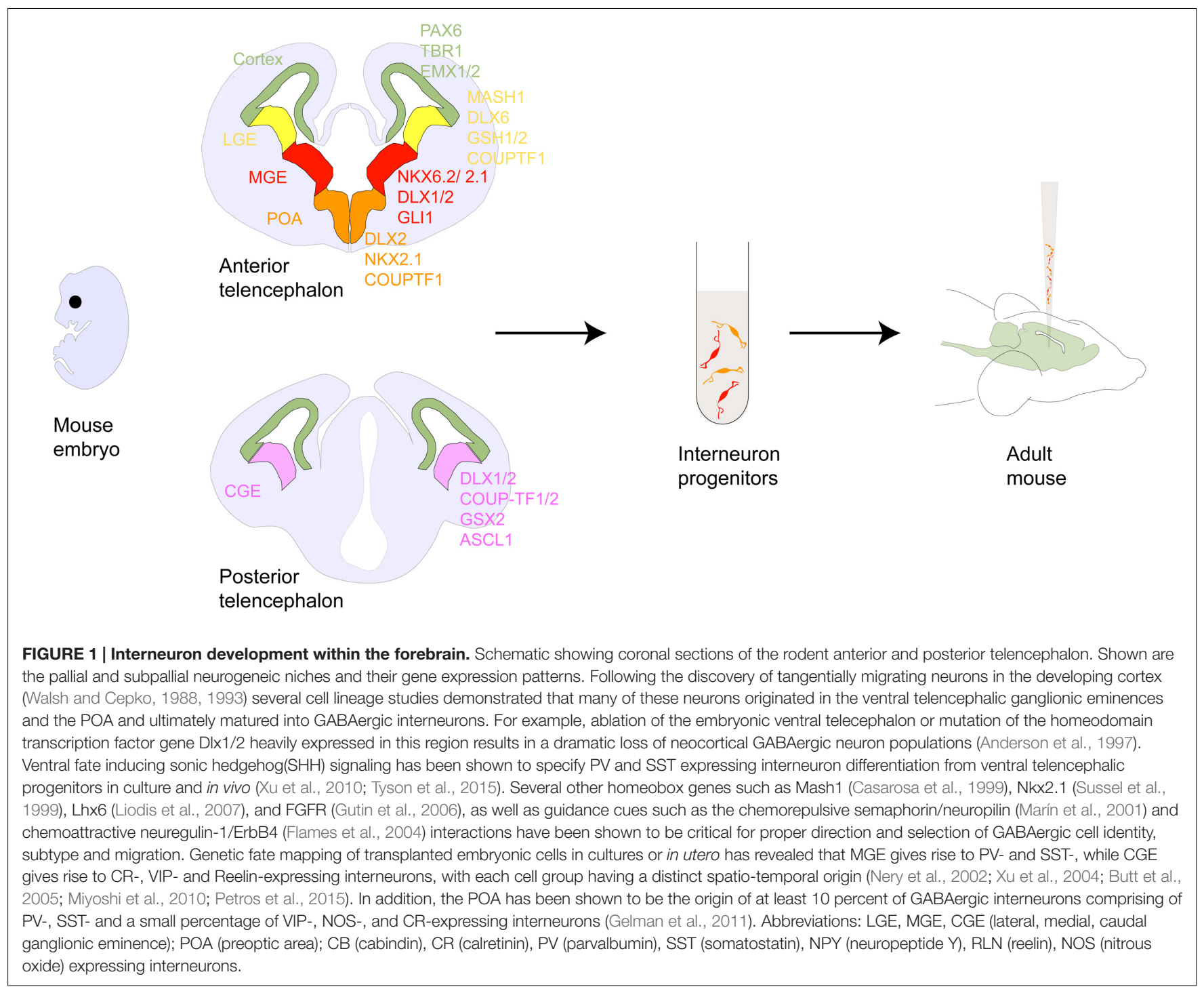

et al., 2009) and granule cells (Henderson et al., 2014), it did not significantly alter IPSC properties of host interneurons (Baraban et al., 2009), whose inhibition is mediated by interneuron subclasses generated from the caudally located CGE cells (Gulyás et al., 1996; Wonders and Anderson, 2006; Caputi et al., 2009). Remarkably, therapeutic efficacy was demonstrated as early as 2.5 weeks following transplantation suggesting possible roles for non-synaptic mechanisms in disease amelioration (Figure 2; De la Cruz et al., 2011). Translational significance of these findings has been tested using transplantation of human pluripotent stem cell derived MGE cells in a pilocarpine-induced temporal lobe epilepsy mouse model (Cunningham et al., 2014; Hunt and Baraban, 2015). While MGE transplants have been shown to increase both synaptic and extrasynaptic inhibition onto host pyramidal neurons (Baraban et al., 2009), activation of extrasynaptic GABA receptors was reported as the basis of MGE precursor transplantation induced amelioration of seizure activity in the cortex (Jaiswal et al., 2015). Given the differential involvement of heterogeneous interneuron populations in the compensatory and epileptogenic mechanisms, including disease initiation and exacerbation (Cohen et al., 2002; Panuccio et al., 2009), GABA interneuron transplants may prove therapeutic for some types or stages of epilepsy. Key to the success of transplants will be to identify which types or stages of epilepsy can benefit and determine the effective composition of the transplant. This will be aided by rapidly developing technologies that allow high throughput generation of developmentally and functionally distinct interneuron subclasses (Doudna and Charpentier, 2014; Colasante et al., 2015).

\section{SCHIZOPHRENIA AND CORTICAL PLASTICITY}

Reductions in SST and PV expressing neurons or functional markers thereof have been observed in the hippocampus and prefrontal cortex in postmortem brains of patients with SCZ (Hashimoto et al., 2003, 2008; Morris et al., 2008; Konradi et al., 


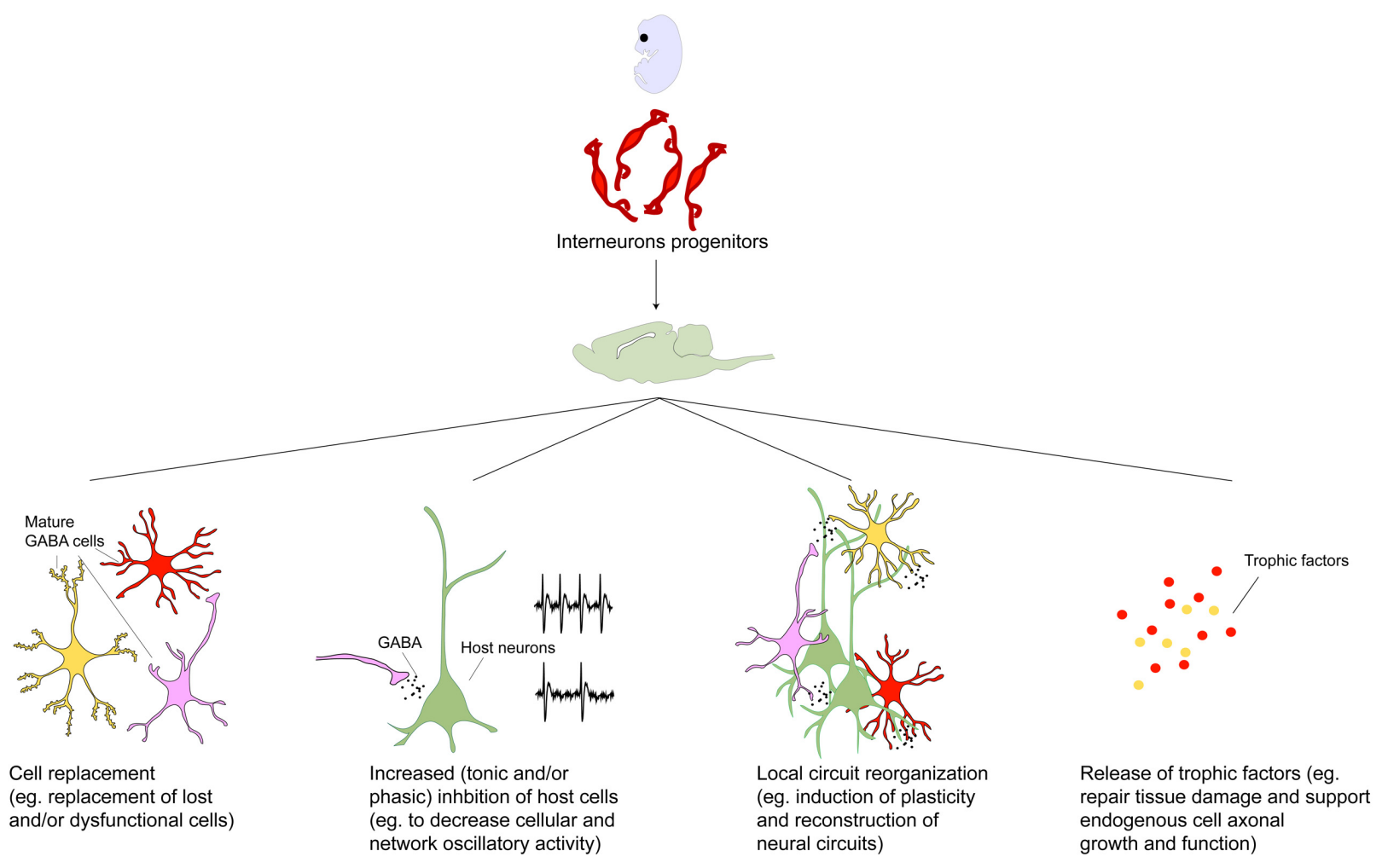

FIGURE 2 | Toward a mechanistic understanding of transplant induced therapeutics. Transplanted GABAergic interneurons make synaptic connections and enhance inhibitory tone within the host brain region (Alvarez-Dolado et al., 2006; Baraban et al., 2009). The importance of these new synaptic connections has been demonstrated in the mature visual cortex where interneuron progenitor implantation but not pharmacological GABA augmentation induces cortical plasticity and reopening of critical period (Fagiolini and Hensch, 2000; Hensch, 2005; Southwell et al., 2010; Davis et al., 2015). This has been attributed to the numerous, individually weak inhibitory connections made by the transplanted neurons which may trigger local circuit reorganization (Southwell et al., 2010). However, given that the behavioral effects of GABAergic interneuron transplants are not phenocopied by local pharmacological enhancement of GABA transmission, and sparseness of transplanted neurons relative to the host population, it has been hypothesized that therapeutic effects of transplants may be mediated by mechanisms beyond that of GABA replacement (Gilani et al., 2014; Southwell et al., 2014). Intriguingly, transplanted neural stem cells have been demonstrated to rescue dysfunctional host dopamine neurons in MPTP-treated aged animals (Ourednik et al., 2002). Other proposed effects independent of synaptic connections with host neurons include secretion of neuroprotective factors (Capone et al., 2007; Redmond et al., 2007; Liang et al., 2014; Goldberg et al., 2015). In addition transplanted neural cells have been proposed to create homeostatic environments by releasing factors that repair and counter inflammation and scarring (Park et al., 2002; Lee et al., 2007). More recently, interrogation of host circuit physiology following engraftment of undifferentiated and non-integrating cells revealed a dose-dependent dampening of cortical excitability and depletion of host cell populations underscoring the importance of engraftment density in designing cell based therapeutic protocols (Weerakkody et al., 2013). Considering the wide-ranging repertoire of transplant-induced effects, discovery of molecular mechanisms underlying these may uncover novel treatment targets in the future.

2011). Indeed, disturbances in synchronous cortical oscillations, generated by fast spiking PV neurons (Sohal et al., 2009) and that are correlated with cognitive functions, are a physiological feature of SCZ (Murray et al., 2011). Moreover, increased hippocampal blood volume, a proxy for metabolic activity, a reliable feature of SCZ and correlate of psychosis, can be produced by functional deficits in GABAergic interneurons (Schobel et al., 2013; Gilani et al., 2014).

Exploring the role of cortical interneurons in schizophreniform cognitive deficits in mice, Tanaka et al. (2011) demonstrated that transplantation of MGE cells in the cortex can prevent phencyclidine induced behavioral deficits, possibly via modulation of local cortical circuitry (Southwell et al., 2010; Howard et al., 2014). Moreover, in a genetic mouse model displaying a relatively selective deficit in hippocampal PV interneurons (Glickstein et al., 2007), transplantation of MGE cells into the hippocampus reversed increased hippocampal activity (as measured with functional magnetic resonance imaging), increased midbrain dopamine neuron activity, increased response to psychostimulants and impaired hippocampus dependent cognition (Gilani et al., 2014). Given the central role of GABA in controlling the timing of critical period plasticity (Hensch, 2005) MGE cells were transplanted in the visual cortex to test whether transplantation of inhibitory cells could induce a plasticity response (Tang et al., 2014). Remarkably, MGE cell transplantation either before (Southwell et al., 2010) or after (Davis et al., 2015) the endogenous critical period induced ocular dominance plasticity and reactivated a new critical period that reversed visual impairments in amblyopic mice. Importantly both PV and SST neuronal populations were shown to be sufficient to drive ocular dominance plasticity but grafts depleted of both PV 
and SST populations were not (Tang et al., 2014). Intriguingly, maturing GABA neurons formed numerous but individually weak synaptic connections with host neurons suggesting a potential reorganization of local cortical circuitry. Sufficiency of both PV and SST interneuron populations to induce plasticity in the visual cortex raises an interesting question as to whether the same also holds true for other brain regions and the spinal cord, as it may have implications for developing refined cell based therapies.

\section{ALZHEIMER'S DISEASE}

GABAergic control of synaptic plasticity is a key aspect of hippocampus dependent learning as it relates to encoding and retrieval of memories (Paulsen and Moser, 1998). AD patients have been shown to have decreased GABA and SST immunoreactivity in the cerebral cortex (Davies et al., 1980; Grouselle et al., 1998), and in late-onset familial and sporadic $\mathrm{AD}$, the risk gene apolipoprotein (apo) E4 polymorphism exacerbates SST dysfunction (Grouselle et al., 1998). In addition, misfolded proteins such as amyloid- $\beta$ that are seen in earlyonset autosomal dominant $\mathrm{AD}$ cause inhibitory interneuron impairments resulting in excitation-inhibition imbalances and network hyperexcitability that is in turn associated with learning and memory deficits (Palop et al., 2007; Andrews-Zwilling et al., 2010; Verret et al., 2012). In particular, PV cell dysfunction has been causally linked to disturbances in cortical network oscillations and cognitive impairments in mice expressing human amyloid precursor protein (Verret et al., 2012). Indeed, AD patients are known to have increased incidence of epileptic events (Amatniek et al., 2006).

In septo-hippocampal lesioned mice, intrahippocampal transplantation of subventricular zone-expanded neural stem cells (Hattiangady and Shetty, 2012) or human embryonic stem cell induced MGE cells (Liu et al., 2013) were shown to reverse learning and memory deficits. Importantly, control experiments involving transplants of spinal progenitors failed to correct these deficits, highlighting the requirement of specific neuronal progenitors in a given target region to achieve functional replacement (Liu et al., 2013). These findings were later extended in two genetic mouse models of AD: apoE4 knock-in mice with or without amyloid- $\beta$ protein accumulation. Importantly, MGE derived cells showed functional integration in the presence of amyloid aggregation and restored cognitive function thus demonstrating interneuron progenitors' ability to integrate and modify diseased circuits in toxic environments (Tong et al., 2014). Given the strong evidence of impaired synaptic inhibition (Busche et al., 2008) and network oscillatory activity (Amatniek et al., 2006) in AD, GABA cell replacement strategies especially those employing fast spiking PV neurons could be a promising therapeutic avenue.

\section{PARKINSON'S DISEASE}

Grafts of dopaminergic cell suspensions into 6-hydroxydopamine (6-OHDA) lesioned striatum are known to restore motor deficits
(Gage et al., 1983). However, a critical limitation of dopaminergic cell grafts is the inability of transplanted cells to disperse in host tissue, limiting the functional recovery to graft site. Intriguingly, local striatal GABAergic interneuron population activity has been shown to sculpt basal ganglia output (Tepper and Bolam, 2004) and abnormalities in inhibitory neurons underlie striatal output imbalances in the dopamine depleted striatum (Mallet et al., 2006). Striatal interneurons may also regulate basal ganglia plasticity (Cazorla et al., 2014) by modulating striatal extrinsic and intrinsic signals and thus may serve as a potential nondopamine locus to lower striatal activity characteristic of PD.

Neurons derived from transplants of MGE tissue in striatum of the 6-OHDA lesioned mice migrate, functionally integrate and improve motor deficits (Martínez-Cerdeño et al., 2010). Under dopamine depleted conditions, striatopallidal neuronal activity is increased while the opposite is true for striatonigral neurons (Shen et al., 2008). Moreover, selective increase in feed-forward inhibition from local PV interneurons onto striatopallidal neurons enhances neural synchrony (Gittis et al., 2011) which may lead to aberrant $\beta$-oscillatory activity characteristic of PD. Overall, GABA tone is increased in the basal ganglia (Borgkvist et al., 2015) leading to persistent suppression of action. Since the transplanted cells show synaptic integration, one possible mechanism of action underlying therapeutic efficacy of MGE cells is the restoration of the balance between the direct and indirect pathways. However, it is notable that a large proportion of donor cells differentiate into oligodendrocytes, implicating nonneuronal support functions provided by the grafts (Figure 2). Intriguingly, MGE transplants made in the subthalamus fail to migrate from the injection site and instead differentiate into glial cells that show long term survival, highlighting the critical role donor-host environmental interactions may play in governing fate of transplanted progenitor cells.

\section{NEUROPATHIC PAIN}

In contrast to cortex, inhibitory interneurons form about 30$40 \%$ of the total neuronal population in the dorsal horn of the spinal cord. By regulating activity of primary afferents, excitatory interneurons, spinal projection neurons and descending fiber tracts, inhibitory interneurons play a crucial role in maintaining a physiological level of pain sensitivity. Disinhibition within the spinal dorsal horn has long been attributed to the symptoms of NP, e.g., GABA neurotransmission is significantly reduced following nerve injury (Moore et al., 2002; Drew et al., 2004) and GABA agonists can ameliorate allodynia and hyperalgesia (Munro et al., 2009). Impaired inhibition, however, results in multiple cellular, molecular and synaptic changes and therapeutic efficacy of currently available anticonvulsantand antidepressant-based pharmacological agents is at best symptomatic and constrained by the drugs' broad mechanisms of actions. Given the ability of interneuron progenitors to functionally integrate in neural tissue and modify inhibitory signaling, interneuron transplantation could serve as a potential disease modifying strategy in NP that is without the adverse side effects associated with systemic medications. 
Surprisingly, transplanted MGE cells into adult spinal cord differentiate into GABA interneuron populations that integrate with the host spinal cord circuitry (Bráz et al., 2012). Contrary to subthalamic MGE grafts that differentiate into glial cells (Martínez-Cerdeño et al., 2010), MGE derived cells in the spinal cord retain their cortical neurochemical profiles suggesting that the latter does not affect MGE differentiation. More importantly, MGE transplantation reversed mechanical hypersensitivity in a mouse model of peripheral nerve injury (Bráz et al., 2012) and mechanical and heat hyperalgesia in a chemotherapy-induced model of NP (Bráz et al., 2015). Notably, transplantation of cells lacking vesicular GABA transporter failed to rescue paclitaxelinduced pain behavior highlighting the critical role of GABAmediated modulation of spinal circuits in transplant efficacy in this pain model (Bráz et al., 2015). Given the problems with tolerance and the sedative and addictive properties of traditional pharmacotherapies, interneuron based therapy may be a promising alternative disease modifying therapeutic option.

\section{CHALLENGES AND PITFALLS IN USING MGE PROGENITOR CELL BASED THERAPY}

While pre-clinical studies have demonstrated promise for interneuron based therapy, cell based approaches have inherent limitations, including but not limited to unpredictable proliferation, differentiation, and migration, leading to pathological ectopia, including tumors. Addressing these limitations will require greater understanding of the mechanisms governing the development and function of the transplants in different brain regions and at different points in the lifespan of the host (Figure 2). Combined with these challenges, incomplete knowledge of the pathophysiology of vast majority of CNS diseases hinders progress to clinical translation. While excitement surrounds generation of GABAergic interneurons from human pluripotent stem cells (Maroof et al., 2013; Wall et al., 2013), current techniques have yet to achieve sufficient efficiency and specificity. Technological innovations are leading to introduction

\section{REFERENCES}

Alvarez-Dolado, M., Calcagnotto, M. E., Karkar, K. M., Southwell, D. G., JonesDavis, D. M., Estrada, R. C., et al. (2006). Cortical inhibition modified by embryonic neural precursors grafted into the postnatal brain. J. Neurosci. 26, 7380-7389. doi: 10.1523/JNEUROSCI.1540-06.2006

Amatniek, J. C., Hauser, W. A., DelCastillo-Castaneda, C., Jacobs, D. M., Marder, K., Bell, K., et al. (2006). Incidence and predictors of seizures in patients with Alzheimer's disease. Epilepsia 47, 867-872. doi: 10.1111/j.15281167.2006.00554.x

Anderson, S. A., Eisenstat, D. D., Shi, L., and Rubenstein, J. L. (1997). Interneuron migration from basal forebrain to neocortex: dependence on dlx genes. Science 278, 474-476. doi: 10.1126/science.278.5337.474

Andrews-Zwilling, Y., Bien-Ly, N., Xu, Q., Li, G., Bernardo, A., Daniel Zwilling, S. Y., et al. (2010). Apolipoprotein E4 causes age- and tau-dependent impairment of GABAergic interneurons, leading to learning and memory deficits in mice. J. Neurosci. 30, 13707-13717. doi: 10.1523/JNEUROSCI.404010.2010 of genetic material into transplanted cells to increase specificity, improvement in production methods allowing more rapid amplification, differentiation of stem cells, and use of cell sorting techniques to select cells on the basis of what will comprise a safe transplant designed specifically to improve function in a given brain region. Identifying host characteristics that can aid survival and guide maturation of the grafted cells in vivo will also address these challenges.

\section{CONCLUSION}

The remarkable capacities of interneuron progenitors to migrate long distances, differentiate into mature interneurons and modify diseased circuits following transplantation have made interneuron based transplantation a viable potential therapeutic approach for CNS diseases. However, further studies in the primate, a refined knowledge of interneuron ontogenesis and development of methods for reliable, high-throughput production of specific GABAergic cell types and safe cell composition of transplants need to be pursued before this approach is realized in the clinical setting. There is reason to be optimistic, given rich and growing literature on interneuron development and rapid growth of technologies that will allow the production of safe and specific transplants.

\section{AUTHOR CONTRIBUTIONS}

MC and HM developed concepts. MC wrote and HM edited the paper.

\section{FUNDING}

This work was supported by New York State Office of Mental Health (HM and MC), Public Health Service Award P01 NS048120 (HM and MC), Sidney R. Baer, Jr. Foundation (HM) and Gray Matters at Columbia Psychiatry (HM).

Arellano, J. I., Muñoz, A., Ballesteros-Yáñez, I., Sola, R. G., and DeFelipe, J. (2004). Histopathology and reorganization of chandelier cells in the human epileptic sclerotic hippocampus. Brain 127, 45-64. doi: 10.1093/brain/ awh004

Banker, G. A., and Cowan, W. M. (1977). Rat hippocampal neurons in dispersed cell culture. Brain Res. 126, 397-425. doi: 10.1016/0006-8993(77)90594-7

Baraban, S. C., Southwell, D. G., Estrada, R. C., Jones, D. L., Sebe, J. Y., AlfaroCervello, C., et al. (2009). Reduction of seizures by transplantation of cortical GABAergic interneuron precursors into Kv1.1 mutant mice. Proc. Natl. Acad. Sci. U.S.A. 106, 15472-15477. doi: 10.1073/pnas.0900141106

Björklund, A., and Stenevi, U. (1984). Intracerebral neural implants: neuronal replacement and reconstruction of damaged circuitries. Annu. Rev. Neurosci. 7, 279-308. doi: 10.1146/annurev.ne.07.030184.001431

Björklund, A., Stenevi, U., and Svendgaard, N. (1976). Growth of transplanted monoaminergic neurones into the adult hippocampus along the perforant path. Nature 262, 787-790. doi: 10.1038/262787a0

Borgkvist, A., Avegno, E. M., Wong, M. Y., Kheirbek, M. A., Sonders, M. S., Hen, R., et al. (2015). Loss of striatonigral GABAergic presynaptic inhibition 
enables motor sensitization in Parkinsonian mice. Neuron 87, 976-988. doi: 10.1016/j.neuron.2015.08.022

Bráz, J. M., Sharif-Naeini, R., Vogt, D., Kriegstein, A., Alvarez-Buylla, A., Rubenstein, J. L., et al. (2012). Forebrain GABAergic neuron precursors integrate into adult spinal cord and reduce injury-induced neuropathic pain. Neuron 74, 663-675. doi: 10.1016/j.neuron.2012.02.033

Bráz, J. M., Wang, X., Guan, Z., Rubenstein, J. L., and Basbaum, A. I. (2015). Transplant-mediated enhancement of spinal cord GABAergic inhibition reverses paclitaxel-induced mechanical and heat hypersensitivity. Pain 156, 1084-1091. doi: 10.1097/j.pain.0000000000000152

Buckmaster, P. S., and Jongen-Rêlo, A. L. (1999). Highly specific neuron loss preserves lateral inhibitory circuits in the dentate gyrus of kainate-induced epileptic rats. J. Neurosci. 19, 9519-9529.

Busche, M. A., Eichhoff, G., Adelsberger, H., Abramowski, D., Wiederhold, K. H., Haass, C., et al. (2008). Clusters of hyperactive neurons near amyloid plaques in a mouse model of Alzheimer's disease. Science 321, 1686-1689. doi: 10.1126/science. 1162844

Butt, S. J., Fuccillo, M., Nery, S., Noctor, S., Kriegstein, A., Corbin, J. G., et al. (2005). The Temporal and spatial origins of cortical interneurons predict their physiological subtype. Neuron 48, 591-604. doi: 10.1016/j.neuron.2005. 09.034

Cajal, S. R. (1928). Degeneration and regeneration of the nervous system. Oxford: Oxford Press, 799-802. doi: 10.1093/acprof:oso/9780195065169.001.0001

Calcagnotto, M. E., Zipancic, I., Piquer-Gil, M., Mello, L. E., and AlvarezDolado, M. (2010). Grafting of GABAergic precursors rescues deficits in hippocampal inhibition. Epilepsia 51(Suppl. 3), 66-70. doi: 10.1111/j.15281167.2010.02613.x

Capone, C., Frigerio, S., Fumagalli, S., Gelati, M., Principato, M.-C., Storini, C., et al. (2007). Neurosphere-derived cells exert a neuroprotective action by changing the ischemic microenvironment. PLOS ONE 2:e373. doi: 10.1371/journal.pone.0000373

Caputi, A., Rozov, A., Blatow, M., and Monyer, H. (2009). Two calretinin-positive gabaergic cell types in layer $2 / 3$ of the mouse neocortex provide different forms of inhibition. Cereb. Cortex 19, 1345-1359. doi: 10.1093/cercor/bhn175

Casarosa, S., Fode, C., and Guillemot, F. (1999). Mash1 regulates neurogenesis in the ventral telencephalon. Development 126, 525-534.

Cazorla, M., de Carvalho, F. D., Chohan, M. O., Shegda, M., Chuhma, N., Rayport, S., et al. (2014). Dopamine D2 receptors regulate the anatomical and functional balance of basal ganglia circuitry. Neuron 81, 153-164. doi: 10.1016/j.neuron.2013.10.041

Clark, W. E. L. (1940). Neuronal differentiation in implanted foetal cortical tissue. J. Neurol. Psychiatry 3, 263-272. doi: 10.1136/jnnp.3.3.263

Cohen, I., Navarro, V., Clemenceau, S., Baulac, M., and Miles, R. (2002). On the origin of interictal activity in human temporal lobe epilepsy in vitro. Science 298, 1418-1421. doi: 10.1126/science.1076510

Colasante, G., Lignani, G., Rubio, A., Medrihan, L., Yekhlef, L., Sessa, A., et al. (2015). Rapid conversion of fibroblasts into functional forebrain GABAergic interneurons by direct genetic reprogramming. Cell Stem Cell 17, 719-734. doi: 10.1016/j.stem.2015.09.002

Cossart, R., Dinocourt, C., Hirsch, J. C., Merchan-Perez, A., De Felipe, J., BenAri, Y., et al. (2001). Dendritic but not somatic GABAergic inhibition is decreased in experimental epilepsy. Nat. Neurosci. 4, 52-62. doi: 10.1038/ 82900

Cummings, B. J., Uchida, N., Tamaki, S. J., Salazar, D. L., Hooshmand, M., Summers, R., et al. (2005). Human neural stem cells differentiate and promote locomotor recovery in spinal cord-injured mice. Proc. Natl. Acad. Sci. U.S.A 102, 14069-14074. doi: 10.1073/pnas.0507063102

Cunningham, M., Cho, J. H., Leung, A., Savvidis, G., Ahn, S., Moon, M., et al. (2014). hPSC-derived maturing GABAergic interneurons ameliorate seizures and abnormal behavior in epileptic mice. Cell Stem Cell 15, 559-573. doi: 10.1016/j.stem.2014.10.006

Davies, P., Katzman, R., and Terry, R. D. (1980). Reduced somatostatin-like immunoreactivity in cerebral cortex from cases of Alzheimer disease and Alzheimer senile dementa. Nature 288, 279-280. doi: 10.1038/288279a0

Davis, M. F., Figueroa Velez, D. X., Guevarra, R. P., Yang, M. C., Habeeb, M., Carathedathu, M. C., et al. (2015). Inhibitory neuron transplantation into adult visual cortex creates a new critical period that rescues impaired vision. Neuron 86, 1055-1066. doi: 10.1016/j.neuron.2015.03.062
De la Cruz, E., Zhao, M., Guo, L., Ma, H., Anderson, S. A., and Schwartz, T. (2011). Interneuron progenitors attenuate the power of acute focal ictal discharges. Neurotherapeutics 8, 763-773. doi: 10.1007/s13311-011-0058-9

de Lanerolle, N. C., Kim, J. H., Robbins, R. J., and Spencer, D. D. (1989). Hippocampal interneuron loss and plasticity in human temporal lobe epilepsy. Brain Res. 495, 387-395. doi: 10.1016/0006-8993(89)90234-5

DeFelipe, J. (1999). Chandelier cells and epilepsy. Brain 122(Pt 10), 1807-1822. doi: 10.1093/brain/122.10.1807

Doudna, J. A., and Charpentier, E. (2014). The New frontier of genome engineering with CRISPR-Cas9. Science 346:1258096. doi: 10.1126/science.12 58096

Drew, G. M., Siddall, P. J., and Duggan, A. W. (2004). Mechanical allodynia following contusion injury of the rat spinal cord is associated with loss of GABAergic inhibition in the dorsal horn. Pain 109, 379-388. doi: 10.1016/j.pain.2004.02.007

Dunn, E. H. (1917). Primary and secondary findings in a series of attempts to transplant cerebral cortex in the albino rat. J. Comp. Neurol. 27, 565-582. doi: $10.1002 /$ cne. 900270403

Fagiolini, M., and Hensch, T. K. (2000). Inhibitory threshold for critical-period activation in primary visual cortex. Nature 404, 183-186. doi: 10.1038/350 04582

Flames, N., Long, J. E., Garratt, A. N., Fischer, T. M., Gassmann, M., Birchmeier, C., et al. (2004). Short- and Long-range attraction of cortical GABAergic interneurons by neuregulin-1. Neuron 44, 251-261. doi: 10.1016/j.neuron.2004.09.028

Fuentealba, L. C., Rompani, S. B., Parraguez, J. I., Obernier, K., Romero, R., Cepko, C. L., et al. (2015). Embryonic origin of postnatal neural stem cells. Cell 161, 1644-1655. doi: 10.1016/j.cell.2015.05.041

Gage, F. H., Björklund, A., Stenevi, U., Dunnett, S. B., and Kelly, P. A. (1984). Intrahippocampal septal grafts ameliorate learning impairments in aged rats. Science 225, 533-536. doi: 10.1126/science.6539949

Gage, N. H., Dunnett, S. B., Stenevi, U., and Björklund, A. (1983). Aged rats: recovery of motor impairments by intrastriatal nigral grafts. Science 221, 966969. doi: $10.1126 /$ science.6879196

Gelman, D., Griveau, A., Dehorter, N., Teissier, A., Varela, C., Pla, R., et al. (2011). A wide diversity of cortical GABAergic interneurons derives from the embryonic preoptic area. J. Neurosci 31, 16570-16580. doi: 10.1523/JNEUROSCI.4068-11.2011

Gilani, A. I., Chohan, M. O., Inan, M., Schobel, S. A., Chaudhury, N. H., Paskewitz, S., et al. (2014). Interneuron precursor transplants in adult hippocampus reverse psychosis-relevant features in a mouse model of hippocampal disinhibition. Proc. Natl. Acad. Sci. U.S.A. 111, 7450-7455. doi: 10.1073/pnas.1316488111

Gittis, A. H., Hang, G. B., LaDow, E. S., Shoenfeld, L. R., Atallah, B. V., Finkbeiner, S., et al. (2011). Rapid target-specific remodeling of fastspiking inhibitory circuits after loss of dopamine. Neuron 71, 858-868. doi: 10.1016/j.neuron.2011.06.035

Glickstein, S. B., Moore, H., Slowinska, B., Racchumi, J., Suh, M., Chuhma, N., et al. (2007). Selective cortical interneuron and GABA deficits in cyclin D2-Null mice. Development 134, 4083-4093. doi: 10.1242/dev.008524

Goldberg, N. R. S., Caesar, J., Park, A., Sedgh, S., Finogenov, G., Masliah, E., et al. (2015). Neural stem cells rescue cognitive and motor dysfunction in a transgenic model of dementia with lewy bodies through a BDNF-dependent mechanism. Stem Cell Rep. 5, 791-804. doi: 10.1016/j.stemcr.2015.09.008

Grouselle, D., Winsky-Sommerer, R., David, J. P., Delacourte, A., Dournaud, P., and Epelbaum, J. (1998). Loss of somatostatin-like immunoreactivity in the frontal cortex of Alzheimer patients carrying the apolipoprotein epsilon 4 allele. Neurosci. Lett. 255, 21-24. doi: 10.1016/S0304-3940(98)00698-3

Gulyás, A. I., Hájos, N., and Freund, T. F. (1996). Interneurons containing calretinin are specialized to control other interneurons in the rat hippocampus. J. Neurosci. 16, 3397-3411.

Gutin, G., Fernandes, M., Palazzolo, L., Paek, H., Yu, K., Ornitz, D. M., et al. (2006). FGF signalling generates ventral telencephalic cells independently of SHH. Development 133, 2937-2946. doi: 10.1242/dev.02465

Hammad, M., Schmidt, S. L., Zhang, X., Bray, R., Frohlich, F., and Ghashghaei, H. T. (2015). Transplantation of GABAergic interneurons into the neonatal primary visual cortex reduces absence seizures in stargazer mice. Cereb. Cortex 25, 2970-2979. doi: 10.1093/cercor/bhu094 
Harrison, P. J. (2015). GABA circuitry, cells and molecular regulation in schizophrenia: life in the graveyard. Schizophr. Res. 167, 108-110. doi: 10.1016/j.schres.2015.02.003

Hashimoto, T., Bazmi, H. H., Mirnics, K., Wu, Q., Sampson, A. R., and Lewis, D. A. (2008). Conserved regional patterns of GABA-related transcript expression in the neocortex of subjects with schizophrenia. Am. J. Psychiatry 165, 479-489. doi: 10.1176/appi.ajp.2007.07081223

Hashimoto, T., Volk, D. W., Eggan, S. M., Mirnics, K., Pierri, J. N., Sun, Z., et al. (2003). Gene expression deficits in a subclass of GABA neurons in the prefrontal cortex of subjects with schizophrenia. J. Neurosci 23, 6315-6326. doi: 10.2967/jnumed.108.060368

Hattiangady, B., and Shetty, A. K. (2012). Neural stem cell grafting counteracts hippocampal injury-mediated impairments in mood, memory, and neurogenesis. Stem Cells Transl. Med. 1, 696-708. doi: 10.5966/sctm.2012-0050

Henderson, K. W., Gupta, J., Tagliatela, S., Litvina, E., Zheng, X. T., Van Zandt, M. A., et al. (2014). Long-term seizure suppression and optogenetic analyses of synaptic connectivity in epileptic mice with hippocampal grafts of GABAergic interneurons. J. Neurosci. 34, 13492-13504. doi: 10.1523/JNEUROSCI.000514.2014

Hensch, T. K. (2005). Critical period plasticity in local cortical circuits. Nat. Rev. Neurosci. 6, 877-888. doi: 10.1038/nrn1787

Howard, M. A., Rubenstein, J. L., and Baraban, S. C. (2014). Bidirectional homeostatic plasticity induced by interneuron cell death and transplantation in vivo. Proc. Natl. Acad. Sci. U.S.A. 111, 492-497. doi: 10.1073/pnas.1307784111

Hunt, R. F., and Baraban, S. C. (2015). Interneuron transplantation as a treatment for epilepsy. Cold Spring Harb. Perspect. Med. 5:a022376. doi: 10.1101/cshperspect.a022376

Hunt, R. F., Girskis, K. M., Rubenstein, J. L., Alvarez-Buylla, A., and Baraban, S. C. (2013). GABA progenitors grafted into the adult epileptic brain control seizures and abnormal behavior. Nat. Neurosci. 16, 692-697. doi: 10.1038/nn.3392

Jaiswal, M. K., Keros, S., Zhao, M., Inan, M., Schwartz, T. H., Anderson, S. A., et al. (2015). Reduction in focal ictal activity following transplantation of MGE interneurons requires expression of the GABAA receptor $\alpha 4$ subunit. Front. Cell. Neurosci. 9:127. doi: 10.3389/fncel.2015.00127

Jakeman, L. B., and Reier, P. J. (1991). Axonal projections between fetal spinal cord transplants and the adult rat spinal cord: a neuroanatomical tracing study of local interactions. J. Comp. Neurol. 307, 311-334. doi: 10.1002/cne.903070211.

Klausberger, T., Magill, P. J., Márton, L. F., Roberts, J. D., Cobden, P. M., Buzsáki, G., et al. (2003). Brain-state- and cell-type-specific firing of hippocampal interneurons in Vivo. Nature 421, 844-848.

Klausberger, T., and Somogyi, P. (2008). Neuronal diversity and temporal dynamics: the unity of hippocampal circuit operations. Science 321, 53-57. doi: $10.1126 /$ science. 1149381

Kobayashi, M., and Buckmaster, P. S. (2003). Reduced inhibition of dentate granule cells in a model of temporal Lobe Epilepsy. J. Neurosci. 23, 2440-2452.

Konradi, C., Yang, C. K., Zimmerman, E. I., Lohmann, K. M., Gresch, P., Pantazopoulos, H., et al. (2011). Hippocampal interneurons are abnormal in schizophrenia. Schizophr. Res. 131, 165-173. doi: 10.1016/j.schres.2011. 06.007

Kromer, L. F., Björklund, A., and Stenevi, U. (1983). Intracephalic embryonic neural implants in the adult rat brain. I. Growth and mature organization of brainstem, cerebellar, and hippocampal implants. J. Comp. Neurol. 218, 433-459. doi: 10.1002/cne.902180408

Lee, J. P., Jeyakumar, M., Gonzalez, R., Takahashi, H., Lee, P. J., Baek, R. C., et al. (2007). Stem cells act through multiple mechanisms to benefit mice with neurodegenerative metabolic disease. Nat. Med. 13, 439-447. doi: $10.1038 / \mathrm{nm} 1548$

Lewis, D. A., Curley, A. A., Glausier, J. R., and Volk, D. W. (2012). Cortical parvalbumin interneurons and cognitive dysfunction in schizophrenia. Trends Neurosci. 35, 57-67. doi: 10.1016/j.tins.2011.10.004

Li, Y., and Raisman, G. (1993). Long axon growth from embryonic neurons transplanted into myelinated tracts of the adult rat spinal cord. Brain Res. 629, 115-127. doi: 10.1016/0006-8993(93)90489-A

Liang, P., Liu, J., Xiong, J., Liu, Q., Zhao, J., Liang, H., et al. (2014). Neural stem cellconditioned medium protects neurons and promotes propriospinal neurons relay neural circuit reconnection after spinal cord injury. Cell Transplant. 23(Suppl. 1), S45-S56. doi: 10.3727/096368914X684989
Liodis, P., Denaxa, M., Grigoriou, M., Akufo-Addo, C., Yanagawa, Y., and Pachnis, V. (2007). Lhx6 activity is required for the normal migration and specification of cortical interneuron subtypes. J. Neurosci. 27, 3078-3089. doi: 10.1523/JNEUROSCI.3055-06.2007

Liu, Y., Weick, J. P., Liu, H., Krencik, R., Zhang, X., Ma, L., et al. (2013). Medial ganglionic eminence-like cells derived from human embryonic stem cells correct learning and memory deficits. Nat. Biotechnol. 31, 440-447. doi: $10.1038 /$ nbt. 2565

Low, W. C., Lewis, P. R., Bunch, S. T., Dunnett, S. B., Thomas, S. R., Iversen, S. D., et al. (1982). Function recovery following neural transplantation of embryonic septal nuclei in adult rats with septohippocampal lesions. Nature 300, 260-262. doi: 10.1038/300260a0

Lu, P., Wang, Y., Graham, L., McHale, K., Gao, M., Wu, D., et al. (2012). Longdistance growth and connectivity of neural stem cells after severe spinal cord injury. Cell 150, 1264-1273. doi: 10.1016/j.cell.2012.08.020

Lund, R. D., and Hauschka, S. D. (1976). Transplanted neural tissue develops connections with host rat brain. Science 193, 582-584.

Mallet, N., Ballion, B., Le Moine, C., and Gonon, F. (2006). Cortical inputs and GABA interneurons imbalance projection neurons in the striatum of parkinsonian rats. J Neurosci. 26, 3875-3884. doi: 10.1523/JNEUROSCI.443905.2006

Marín, O., Yaron, A., Bagri, A., Tessier-Lavigne, M., and Rubenstein, J. L. (2001). Sorting of striatal and cortical interneurons regulated by semaphorinneuropilin interactions. Science 293, 872-875. doi: 10.1126/science. 1061891

Maroof, A. M., Keros, S., Tyson, J. A., Ying, S. W., Ganat, Y. M., Merkle, F. T., et al. (2013). Directed differentiation and functional maturation of cortical interneurons from human embryonic stem cells. Cell Stem Cell 12, 559-572. doi: 10.1016/j.stem.2013.04.008

Martínez-Cerdeño, V., Noctor, S. C., Espinosa, A., Ariza, J., Parker, P., Orasji, S., et al. (2010). Embryonic MGE precursor cells grafted into adult rat striatum integrate and ameliorate motor symptoms in 6-OHDA-lesioned rats. Cell Stem Cell 6, 238-250. doi: 10.1016/j.stem.2010.01.004

Mathern, G. W., Babb, T. L., Pretorius, J. K., and Leite, J. P. (1995). Reactive synaptogenesis and neuron densities for neuropeptide, Y., somatostatin, and glutamate decarboxylase immunoreactivity in the epileptogenic human fascia dentata. J. Neurosci. 15(5 Pt 2), 3990-4004.

Merkle, F. T., and Alvarez-Buylla, A. (2006). Neural stem cells in mammalian development. Curr. Opin. Cell Biol. 18, 704-709. doi: 10.1016/j.ceb.2006. 09.008

Miyoshi, G., Hjerling-Leffler, J., Karayannis, T., Sousa, V. H., Butt, S. J. B., Battiste, J., et al. (2010). Genetic fate mapping reveals that the caudal ganglionic eminence produces a large and diverse population of superficial cortical interneurons. J. Neurosci. 30, 1582-1594. doi: 10.1523/JNEUROSCI.451509.2010

Möhler, H., Fritschy, J.-M., Crestani, F., Hensch, T., and Rudolph, U. (2004). Specific GABA(A) circuits in brain development and therapy. Biochem. Pharmacol. 68, 1685-1690. doi: 10.1016/j.bcp.2004.07.025

Moore, K. A., Kohno, T., Karchewski, L. A., Scholz, J., Baba, H., and Woolf, C. J. (2002). Partial peripheral nerve injury promotes a selective loss of GABAergic inhibition in the superficial dorsal horn of the spinal cord. J. Neurosci. 22, 6724-6731.

Morris, H. M., Hashimoto, T., and Lewis, D. A. (2008). Alterations in somatostatin mRNA expression in the dorsolateral prefrontal cortex of subjects with schizophrenia or schizoaffective disorder. Cerebral Cortex 18, 1575-1587. doi: 10.1093/cercor/bhm186

Munro, G., Ahring, P. K., and Mirza, N. R. (2009). Developing analgesics by enhancing spinal inhibition after injury: GABAA receptor subtypes as novel targets. Trends Pharmacol. Sci. 30, 453-459. doi: 10.1016/j.tips.2009. 06.004

Muotri, A. R., and Gage, F. H. (2006). Generation of neuronal variability and complexity. Nature 441, 1087-1093. doi: 10.1038/nature04959

Murray, A. J., Sauer, J. F., Riedel, G., McClure, C., Ansel, L., Cheyne, L., et al. (2011). Parvalbumin-positive CA1 interneurons are required for spatial working but not for reference memory. Nat. Neurosci. 14, 297-299. doi: 10.1038/nn.2751

Nery, S., Fishell, G., and Corbin, J. G. (2002). The caudal ganglionic eminence is a source of distinct cortical and subcortical cell populations. Nat. Neurosci. 5, 1279-1287. doi: 10.1038/nn971 
Nornes, H., Bjorklund, A., and Stenevi, U. (1983). Reinnervation of the denervated adult spinal cord of rats by intraspinal transplants of embryonic brain stem neurons. Cell Tissue Res. 230, 15-35. doi: 10.1007/BF00216024

Ogiwara, I., Miyamoto, H., Morita, N., Atapour, N., Mazaki, E., Inoue, I., et al. (2007). Nav1.1 localizes to axons of parvalbumin-positive inhibitory interneurons: a circuit basis for epileptic seizures in mice carrying an scnla gene mutation. J. Neurosci. 27, 5903-5914. doi: 10.1523/JNEUROSCI.527006.2007

Ourednik, J., Ourednik, V., Lynch, W. P., Schachner, M., and Snyder, E. Y. (2002). Neural stem cells display an inherent mechanism for rescuing dysfunctional neurons. Nat. Biotechnol. 20, 1103-1110. doi: 10.1038/nbt750

Palop, J. J., Chin, J., Roberson, E. D., Wang, J., Thwin, M. T., Bien-Ly, N., et al. (2007). Aberrant excitatory neuronal activity and compensatory remodeling of inhibitory hippocampal circuits in mouse models of alzheimer's disease. Neuron 55, 697-711. doi: 10.1016/j.neuron.2007.07.025

Panuccio, G., Curia, G., Colosimo, A., Cruccu, G., and Avoli, M. (2009). Epileptiform synchronization in the cingulate cortex. Epilepsia 50, 521-536. doi: 10.1111/j.1528-1167.2008.01779.x

Park, K. I., Teng, Y. D., and Snyder, E. Y. (2002). The injured brain interacts reciprocally with neural stem cells supported by scaffolds to reconstitute lost tissue. Nat. Biotechnol. 20, 1111-1117. doi: 10.1038/nbt751

Paulsen, O., and Moser, E. I. (1998). A model of hippocampal memory encoding and retrieval: GABAergic control of synaptic plasticity. Trends Neurosci. 21, 273-278. doi: 10.1016/S0166-2236(97)01205-8

Peñagarikano, O., Abrahams, B. S., Herman, E. I., Winden, K. D., Gdalyahu, A., Dong, H., et al. (2011). Absence of CNTNAP2 leads to epilepsy, neuronal migration abnormalities, and core autism-related deficits. Cell 147, 235-246. doi: 10.1016/j.cell.2011.08.040

Petros, T. J., Bultje, R. S., Ross, M. E., Fishell, G., and Anderson, S. A. (2015). Apical versus basal neurogenesis directs cortical interneuron subclass fate. Cell Rep. 13, 1090-1095. doi: 10.1016/j.celrep.2015.09.079

Redmond, DE Jr, Bjugstad, K. B., Teng, Y. D., Ourednik, V., Ourednik, J., Wakeman, D. R., et al. (2007). Behavioral improvement in a primate parkinson's model is associated with multiple homeostatic effects of human neural stem cells. Proc. Natl. Acad. Sci. U. S.A. 104, 12175-12180. doi: 10.1073/pnas.0704091104

Salin, P., López, I. P., Kachidian, P., Barroso-Chinea, P., Rico, A. J., GómezBautista, V., et al. (2009). Changes to interneuron-driven striatal microcircuits in a rat model of parkinson's disease. Neurobiol. Dis. 34, 545-552. doi: 10.1016/j.nbd.2009.03.006

Schobel, S. A., Chaudhury, N. H., Khan, U. A., Paniagua, B., Styner, M. A., Asllani, I., et al. (2013). Imaging patients with psychosis and a mouse model establishes a spreading pattern of hippocampal dysfunction and implicates glutamate as a driver. Neuron 78, 81-93. doi: 10.1016/j.neuron.2013. 02.011

Shen, W., Flajolet, M., Greengard, P., and Surmeier, D. J. (2008). Dichotomous dopaminergic control of striatal synaptic plasticity. Science 321, 848-851. doi: 10.1126/science. 1160575

Shyh-Chang, N., Daley, G. Q., and Cantley, L. C. (2013). Stem cell metabolism in tissue development and aging. Development 140, 2535-2547. doi: 10.1242/dev.091777

Sloviter, R. S. (1987). Decreased hippocampal inhibition and a selective loss of interneurons in experimental epilepsy. Science 235, 73-76. doi: $10.1126 /$ science. 2879352

Sohal, V. S., Zhang, F., Yizhar, O., and Deisseroth, K. (2009). Parvalbumin neurons and gamma rhythms enhance cortical circuit performance. Nature 459, 698 702. doi: $10.1038 /$ nature 07991

Southwell, D. G., Froemke, R. C., Alvarez-Buylla, A., Stryker, M. P., and Gandhi, S. P. (2010). Cortical plasticity induced by inhibitory neuron transplantation. Science 327, 1145-1148. doi: 10.1126/science.1183962

Southwell, D. G., Nicholas, C. R., Basbaum, A. I., Stryker, M. P., Kriegstein, A. R., Rubenstein, J. L., et al. (2014). Interneurons from embryonic development to cell-based therapy. Science 344:1240622. doi: 10.1126/science.1240622

Sundstrom, L. E., Brana, C., Gatherer, M., Mepham, J., and Rougier, A. (2001). Somatostatin- and neuropeptide Y-synthesizing neurones in the fascia dentata of humans with temporal lobe epilepsy. Brain 124, 688-697. doi: 10.1093/brain/124.4.688
Sussel, L., Marin, O., Kimura, S., and Rubenstein, J. L. (1999). Loss of Nkx2.1 homeobox gene function results in a ventral to dorsal molecular respecification within the basal telencephalon: evidence for a transformation of the pallidum into the striatum. Development 126, 3359-3370.

Tanaka, D. H., Toriumi, K., Kubo, K., Nabeshima, T., and Nakajima, K. (2011). GABAergic precursor transplantation into the prefrontal cortex prevents phencyclidine-induced cognitive deficits. J. Neurosci. 31, 14116-14125. doi: 10.1523/JNEUROSCI.2786-11.2011

Tang, Y., Stryker, M. P., Alvarez-Buylla, A., and Espinosa, J. S. (2014). Cortical plasticity induced by transplantation of embryonic somatostatin or parvalbumin interneurons. Proc. Natl. Acad. Sci. U.S.A. 111, 18339-18344. doi: $10.1073 /$ pnas. 1421844112

Tepper, J. M., and Bolam, J. P. (2004). Functional diversity and specificity of neostriatal interneurons. Curr. Opin. Neurobiol. 14, 685-692. doi: 10.1016/j.conb.2004.10.003

Tidd, C. W. (1932). The transplantation of spinal ganglia in the white rat. A study of the morphological changes in surviving cells. J. Comp. Neurol. 55, 531-543. doi: $10.1002 /$ cne. 900550213

Tong, L. M., Djukic, B., Arnold, C., Gillespie, A. K., Yoon, S. Y., Wang, M. M., et al. (2014). Inhibitory interneuron progenitor transplantation restores normal learning and memory in ApoE4 knock-in mice without or with $A \beta$ accumulation. J. Neurosci. 34, 9506-9515. doi: 10.1523/JNEUROSCI.069314.2014

Tricoire, L., Pelkey, K. A., Erkkila, B. E., Jeffries, B. W., Yuan, X., and McBain, C. J. (2011). A blueprint for the spatiotemporal origins of mouse hippocampal interneuron diversity. J. Neurosci. 31, 10948-10970. doi: 10.1523/JNEUROSCI.0323-11.2011

Tyson, J. A., Goldberg, E. M., Maroof, A. M., Xu, Q., Petros, T. J., and Anderson, S. A. (2015). Duration of culture and sonic hedgehog signaling differentially specify PV versus SST cortical interneuron fates from embryonic stem cells. Development 142, 1267-1278. doi: 10.1242/dev.111526

Verret, L., Mann, E. O., Hang, G. B., Barth, A. M., Cobos, I., Ho, K., et al. (2012). Inhibitory interneuron deficit links altered network activity and cognitive dysfunction in alzheimer model. Cell 149, 708-721. doi: 10.1016/j.cell.2012.02.046

Waldau, B., Hattiangady, B., Kuruba, R., and Shetty, A. K. (2010). Medial ganglionic eminence-derived neural stem cell grafts ease spontaneous seizures and restore GDNF expression in a rat model of chronic temporal lobe epilepsy. Stem Cells 28, 1153-1164. doi: 10.1002/stem.446

Wall, N. R., De La Parra, M., Callaway, E. M., and Kreitzer, A. C. (2013). Differential innervation of direct- and indirect-pathway striatal projection neurons. Neuron 79, 347-360. doi: 10.1016/j.neuron.2013.05.014

Walsh, C., and Cepko, C. (1988). Clonally related cortical cells show several migration patterns. Science 241, 1342-1345. doi: 10.1126/science. 3137660

Walsh, C., and Cepko, C. L. (1993). Clonal dispersion in proliferative layers of developing cerebral cortex. Nature 362, 632-635. doi: 10.1038/ $362632 \mathrm{a} 0$

Weerakkody, T. N., Patel, T. P., Yue, C., Takano, H., Anderson, H. C., Meaney, D. F., et al. (2013). Engraftment of nonintegrating neural stem cells differentially perturbs cortical activity in a dose-dependent manner. Mol. Therapy $21,2258-$ 2267. doi: $10.1038 / \mathrm{mt} .2013 .163$

Willis, R. A. (1935). Experiments on the intracerebral implantation of embryo tissues in rats. Proc. R. Soc. Lond. B. Biol. Sci. 117, 400-412. doi: 10.1098/rspb.1935.0036

Wittner, L., Eross, L., Czirják, S., Halász, P., Freund, T. F., and Maglóczky, Z. (2005). Surviving CA1 pyramidal cells receive intact perisomatic inhibitory input in the human epileptic hippocampus. Brain 128, 138-152. doi: 10.1093/brain/ awh339

Wittner, L., Eross, L., Szabó, Z., Tóth, S., Czirják, S., Halász, P., et al. (2002). Synaptic reorganization of calbindin-positive neurons in the human hippocampal CA1 region in temporal lobe epilepsy. Neuroscience 115, 961-978. doi: 10.1016/S0306-4522(02)00264-6

Wittner, L., Maglóczky, Z., Borhegyi, Z., Halász, P., Tóth, S., Eross, L., et al. (2001). Preservation of perisomatic inhibitory input of granule cells in the epileptic human dentate gyrus. Neuroscience 108, 587-600. doi: 10.1016/S03064522(01)00446-8 
Wonders, C. P., and Anderson, S. A. (2006). The origin and specification of cortical interneurons. Nat. Rev. Neurosci. 7, 687-696. doi: 10.1038/ nrn1954

Xu, Q., Cobos, I., De La Cruz, E., Rubenstein, J. L., and Anderson, S. A. (2004), Origins of cortical interneuron subtypes. J. Neurosci. 24, 2612-2622. doi: 10.1523/JNEUROSCI.5667-03.2004

Xu, Q., Guo, L., Moore, H., Waclaw, R. R., Campbell, K., and Anderson, S. A. (2010). Sonic hedgehog signaling confers ventral telencephalic progenitors with distinct cortical interneuron fates. Neuron 65, 328-340. doi: 10.1016/j.neuron.2010.01.004
Conflict of Interest Statement: The authors declare that the research was conducted in the absence of any commercial or financial relationships that could be construed as a potential conflict of interest.

Copyright (C) 2016 Chohan and Moore. This is an open-access article distributed under the terms of the Creative Commons Attribution License (CC BY). The use, distribution or reproduction in other forums is permitted, provided the original author(s) or licensor are credited and that the original publication in this journal is cited, in accordance with accepted academic practice. No use, distribution or reproduction is permitted which does not comply with these terms. 